\title{
Penicillin-Binding Proteins in the Soluble Fraction of Caulobacter crescentus
}

\author{
By SHIGEO KOYASU,* AKIO FUKUDA AND YOSHIMI OKADA \\ Department of Biophysics and Biochemistry, Faculty of Science, University of Tokyo, Hongo, \\ Tokyo 113, Japan
}

(Received 17 June 1981; revised 1 September 1981)

\begin{abstract}
Four penicillin-binding proteins (PBPs) were observed in the soluble fraction of Caulobacter crescentus CB 13, and designated PBP S1 (mol. wt 60000), PBP S2 (55000), PBP S3 (45 000) and PBP S4 (40000). Caulobacter crescentus CB 15, an independent isolate, possessed similar soluble PBPs, but not PBP S2. These soluble PBPs could be observed even when a cell suspension was directly reacted with $\left[{ }^{14} \mathrm{C}\right]$ penicillin $\mathrm{G}$. Two of the soluble PBPs, S1 and S2, released half their bound $\left[{ }^{14} \mathrm{C}\right]$ penicillin $\mathrm{G}$ during a $10 \mathrm{~min}$ incubation, indicating that these PBPs have penicillinase-like activity. PBP S2 was very thermolabile and lost its penicillinbinding activity after incubation at $40^{\circ} \mathrm{C}$ for $10 \mathrm{~min}$. Mecillinam did not show selective binding to any of the Caulobacter soluble PBPs or to PBPs in the cell envelope.
\end{abstract}

\section{INTRODUCTION}

The Gram-negative stalked bacterium Caulobacter is characterized by the presence of two identical chromosomes in one cell (Iba \& Okada, 1980), by a unique cell division pathway where functionally and morphologically different daughter cells are produced, and by a sequence of events which leads to the morphogenesis of surface structures at the poles of the cell at a defined time in the growth cycle (Poindexter, 1964, 1981; Shapiro, 1976). Recent studies have revealed that penicillin-binding proteins (PBPs) of bacteria play essential roles in cell wall formation, cell division and cell morphogenesis (Spratt, 1975, 1977 b; Tamaki et al., 1977; Iwaya et al., 1978; Suzuki et al., 1978). Caulobacter species possess PBPs in their cell envelope which are markedly different, in molecular weight and properties, from those of other bacteria.

It was reported previously (Koyasu et al., $1980 a$, 1981) that several Caulobacter strains possessed at least five major PBPs, namely PBP1A (mol. wt 132000), PBP1Bs (98000), PBP2 (77000), PBP3 (64000) and PBP4 (50000). One of the strains, C. crescentus CB13, lacked PBP4. However, no low molecular weight PBPs equivalent to PBP5 and PBP6 of Escherichia coli or other genera were detected (Shepherd et al., 1977; Chase et al., 1978; Curtis et al., 1979; Noguchi et al., 1979; Ohya et al., 1979; Coyette et al., 1980). In addition, none of the Caulobacter envelope PBPs showed penicillinase activity. In many other bacteria, PBPs of low molecular weight possess penicillinase activity (Shepherd et al., 1977; Spratt, i977a; Chase et al., 1978; Noguchi et al., 1979; Ohya et al., 1979). Caulobacter also apparently lacks the mecillinam target equivalent to PBP2 of E. coli (Spratt \& Pardee, 1975). Finally, PBP4 of Caulobacter was located in the outer membrane fraction, in contrast to other bacterial PBPs which are located only in the inner membrane (Spratt, 1977a; Noguchi et al., 1979; Koyasu et al., 1980a).

In addition to the well-characterized envelope PBPs, recent studies have indicated the presence of soluble PBPs in Streptomyces (Leyh-Bouille et al., 1977; Ogawara \& Horikawa, 1980), E. coli (Koyasu et al., 1980 b) and Streptococcus (Coyette et al., 1980). The functions 
of soluble PBPs are not clear at the moment, but it was of interest to investigate possible PBPs in a stalked bacterium and to study any relationship to morphogenesis in this organism. We describe in this paper four possible soluble PBPs in C. crescentus.

\section{METHODS}

Bacterial strains and growth conditions. Caulobacter crescentus wild-type strains CB 13 and CB15 were used. The bacteria were grown in polypeptone/yeast extract (PYE) nutrient broth at $30^{\circ} \mathrm{C}$.

Fractionation of cell components. Bacteria were harvested from 2-litre cultures in the late-exponential phase of growth, washed with $10 \mathrm{mM}$-sodium phosphate buffer, $\mathrm{pH} 7.0$, suspended in $10 \mathrm{ml}$ of the same buffer and sonicated by a Branson Sonifier at setting 5 for $10 \mathrm{~min}$ at $0^{\circ} \mathrm{C}$. Unbroken cells were removed by low-speed centrifugation. The homogenates were centrifuged at $100000 \mathrm{~g}$ for $30 \mathrm{~min}$ at $4{ }^{\circ} \mathrm{C}$. The sediments (envelopes) were washed with $10 \mathrm{~mm}$-sodium phosphate buffer, $\mathrm{pH} 7 \cdot 0$, and suspended in $1 \mathrm{ml}$ of the same buffer. The supernatant fluid was further centrifuged at $100000 \mathrm{~g}$ for $3.5 \mathrm{~h}$ at $4{ }^{\circ} \mathrm{C}$. The upper and lower portions of the supernatant were recovered separately as $\mathrm{S} 100$ and $\mathrm{S} 100^{\prime}$ fractions, respectively. The ribosomal sediments (ribosomes containing remaining small vesicles of cell envelopes) were suspended in $1 \mathrm{ml} 10 \mathrm{~mm}$-sodium phosphate buffer, $\mathrm{pH} 7 \cdot 0$. Protein recovery of each fraction was determined by the Lowry method with bovine serum albumin as the reference protein. All samples were stored at $-70^{\circ} \mathrm{C}$.

Binding of $\left[{ }^{14} \mathrm{C}\right.$ penicillin $\mathrm{G}$ and release of bound $\left[{ }^{14} \mathrm{C} \mid\right.$ penicillin $\mathrm{G}$. Penicillin-binding proteins were assayed as described previously (Koyasu et al., 1980a, 1981). Briefly, samples, $30 \mu \mathrm{l}$ in volume or $240 \mu \mathrm{g}$ protein-equivalent, were incubated with $3 \mu \mathrm{l}\left[{ }^{14} \mathrm{C}\right.$ penicillin $\mathrm{G}$ at various concentrations at $30^{\circ} \mathrm{C}$ for $10 \mathrm{~min}$, mixed with $3 \mu \mathrm{l}$ of a solution containing $3.4 \%(\mathrm{w} / \mathrm{v})$ Sarkosyl and $6 \%(\mathrm{w} / \mathrm{v})$ non-radioactive penicillin $\mathrm{G}$ and further incubated at $20^{\circ} \mathrm{C}$ for at least $20 \mathrm{~min}$. The mixture was centrifuged at $15000 \mathrm{~g}$ for $15 \mathrm{~min}$. To $30 \mu \mathrm{l}$ of the supernatant were added $15 \mu \mathrm{l}$ gel sample buffer $[0.2 \mathrm{M}$-Tris/HCl, $\mathrm{pH} 6 \cdot 8,3 \%(\mathrm{w} / \mathrm{v})$ sodium dodecyl sulphate (SDS), $30 \%(\mathrm{w} / \mathrm{v})$ glycerol, $0.002 \%(\mathrm{w} / \mathrm{v})$ bromophenol bluel and $5 \mu \mathrm{l} \beta$-mercaptoethanol. The mixture was heated at $90^{\circ} \mathrm{C}$ for $2 \mathrm{~min}$ before electrophoresis.

The rate of release of bound $\left[{ }^{14} \mathrm{C}\right.$ |penicillin $\mathrm{G}$ from PBPs was measured as described previously (Spratt, $1977 \mathrm{a}$; Koyasu et al., 1981). Samples $(30 \mu \mathrm{l})$ were first incubated with $\left[{ }^{14} \mathrm{C}\right.$ lpenicillin $\mathrm{G}\left(200 \mu \mathrm{g} \mathrm{ml}{ }^{-1}\right)$ at $30^{\circ} \mathrm{C}$ for $10 \mathrm{~min}$, and then mixed with $3 \mu \mathrm{l}$ non-radioactive penicillin $\mathrm{G}\left(180 \mathrm{mg} \mathrm{ml}^{-1}\right)$ and further incubated at $30^{\circ} \mathrm{C}$. After different times, $2 \mu \mathrm{l}$ portions of $5 \%$ Sarkosyl were added and the remaining radioactivity of bound $\left[{ }^{14} \mathrm{C}\right]$ penicillin $G$ was assayed by electrophoresis and fluorography.

Binding of $\left[{ }^{14} C\right.$ Clpenicillin $G$ to intact cells. Bacteria were grown in PYE medium, harvested in the late-exponential phase of growth and suspended in $10 \mathrm{mM}$-sodium phosphate buffer, $\mathrm{pH} 7.0$ (about $10^{11} \mathrm{cells} \mathrm{ml}^{-1}$ or $100 \mathrm{mg}$ wet weight $\mathrm{ml}^{-1}$ ). A $30 \mu \mathrm{l}$ portion of the cell suspension was incubated with $3 \mu \mathrm{l}$ of various concentrations of $\left[{ }^{14} \mathrm{C}\right.$ penicillin $\mathrm{G}$ at $30^{\circ} \mathrm{C}$ for $10 \mathrm{~min}$, mixed with $3 \mu$ of a solution containing $3.4 \%$ Sarkosyl and $6 \%$ non-radioactive penicillin $\mathrm{G}$ and incubated at $20^{\circ} \mathrm{C}$ for at least $20 \mathrm{~min}$. The mixture was then centrifuged at $15000 \mathrm{~g}$ for $15 \mathrm{~min}$. To $30 \mu \mathrm{l}$ of the supernatant were added $15 \mu \mathrm{lgel}$ sample buffer and $5 \mu \mathrm{l} \beta$-mercaptoethanol. The mixture was heated at $90^{\circ} \mathrm{C}$ for 2 min before electrophoresis. The above concentration of Sarkosyl was enough to solubilize all PBPs. The use of higher concentrations of Sarkosyl to solubilize additional envelope components caused severe disturbance of the subsequent electrophoretic analysis.

Affinities of $\beta$-lactam antibiotics for PBPs. The pre-addition method (Spratt, 1977 a; Koyasu et al., 1981) was used. Samples, $27 \mu \mathrm{l}$ in volume or $220 \mu \mathrm{g}$ protein-equivalent, were incubated with $3 \mu \mathrm{l}$ of a $\beta$-lactam antibiotic at various concentrations at $30^{\circ} \mathrm{C}$ for $10 \mathrm{~min}$, then mixed with $3 \mu \mathrm{l}\left[{ }^{14} \mathrm{C} /\right.$ penicillin $\mathrm{G}$ (final concentration $100 \mu \mathrm{g} \mathrm{ml}^{-1}$ ) and further incubated at $30^{\circ} \mathrm{C}$ for $10 \mathrm{~min}$. The binding was terminated by the addition of $3 \mu \mathrm{l}$ of a solution containing $3.4 \%$ Sarkosyl and $6 \%$ non-radioactive penicillin G.

Slab gel electrophoresis and fluorography. The gel was $2 \mathrm{~mm}$ thick. Two different SDS-polyacrylamide gel systems were used. The running gel was $7.5 \%(\mathrm{w} / \mathrm{v})$ acrylamide, $0.1 \%(\mathrm{w} / \mathrm{v})$ (system 1$)$ or $0.05 \%$ (system 2) $N, N^{\prime}$-methylenebisacrylamide, $0.1 \%$ SDS in $0.375 \mathrm{~m}$-Tris/ $/ \mathrm{HCl}, \mathrm{pH} 8.9$; the stacking gel was $3.75 \%$ acrylamide, $0.05 \% N, N^{\prime}$-methylenebisacrylamide, $0.1 \%$ SDS in $0.25 \mathrm{M}$-Tris $/ \mathrm{HCl}, \mathrm{pH} 6.8$. The running buffer was $0.05 \mathrm{M}$-Tris $/ 0.384 \mathrm{M}$-glycine $/ 0.1 \%$ SDS. Electrophoresis was carried out at $25 \mathrm{~mA}$ for $6 \mathrm{~h}$ at room temperature.

Fluorography was carried out as described by Bonner \& Laskey (1974) and Laskey \& Mills (1975). The gel was impregnated with 2,5-diphenyloxazole, dried on a filter paper and exposed to a pre-fogged Kodak X Omat $\mathbf{R}$ $\mathrm{X}$-ray film at $-80^{\circ} \mathrm{C}$ for at least 3 weeks. For quantitative analysis, the film was cut into strips and scanned by a Gilford gel scanner. The peak area was measured and corrections were made for differences in the width of gel slots when necessary.

Chemicals. $\left[{ }^{14} \mathrm{C}\right.$ Penicillin $\mathrm{G}$ (50 to $60 \mathrm{Ci} \mathrm{mol}^{-1}: 1.8$ to $2.2 \mathrm{TBq} \mathrm{mol}^{-1}$ ) was purchased from Amersham. Apalcillin, cephaloridine, penicillin $\mathrm{G}$ and mecillinam were obtained from Sumitomo Chemical Co., Osaka, Takeda Pharmaceutical Industries Co., Osaka, Meiji Seika Co.. Tokyo and Leo Pharmaceutical Products, Denmark, respectively. 


\section{RES ULT S}

Presence of PBPs in the soluble fraction. In order to test whether PBPs exist in the soluble fraction, $C$. crescentus CB 13 cell components were fractionated as described in Methods. The protein content of each fraction from a 2-litre culture was as follows: homogenate, $320 \mathrm{mg}$; supernatant after centrifuging at $100000 \mathrm{~g}$ for $30 \mathrm{~min}, 200 \mathrm{mg}$; cell envelopes, $47 \mathrm{mg}$; S100 fraction, $32 \mathrm{mg}$; $\mathrm{S} 100^{\prime}$ fraction, $71 \mathrm{mg}$; ribosomal fraction, $71 \mathrm{mg}$. PBPs were assayed in each fraction by using gel system 2, by which clear separation of high molecular weight PBP1Bs may be achieved (Fig. 1), or by gel system 1, by which clear separation of low molecular weight PBPs may be achieved (Fig. 2).

In the soluble S100 fraction (Fig. 1c, Fig. 2c), at least four new PBPs were clearly detected in the low molecular weight regions of the gel. The cell envelopes (Fig. 1f) contained PBPs of high molecular weight as reported previously (Koyasu et al., 1980a, 1981). These soluble PBPs were designated PBP S1, PBP S2, PBP S3 and PBP S4, having apparent molecular weights of $60000,55000,45000$ and 40000 , respectively. A minor band of molecular weight 42000 and a few additional bands of low molecular weight were sometimes detected (Fig. $1 c$, $d$; Fig. $2 c$ ). Strong sonication probably produces minute membrane vesicles which may contaminate the soluble fraction. When cells were sonicated only briefly, the above PBPs were still observed exclusively in the soluble fraction (S100 and S100' fractions).

These PBPs were observed even when phenylmethylsulphonylfluoride, a serine protease inhibitor, was present during preparation of the $\$ 100$ fraction. When the envelopes were incubated at $30^{\circ} \mathrm{C}$ prior to the PBP assay, the soluble PBPs did not appear. When the homogenates were incubated at $30^{\circ} \mathrm{C}$ prior to the PBP assay, the amounts of the soluble PBPs did not change.

For comparative purposes, soluble S100 fraction of C. crescentus CB 15 was prepared and reacted with $\left[{ }^{14} \mathrm{C}\right]$ penicillin G. As shown in Fig. 2, the soluble PBPs of the two strains of Caulobacter were quite similar: strain CB15 possessed PBP S1, PBP S3, PBP S4 and an additional band of molecular weight of 35000 , but did not possess PBP S2.

Binding of $\left[{ }^{14} \mathrm{C}\right]$ penicillin $G$ to $P B P S$ in intact cells and in the soluble fraction. A suspension of intact bacteria was reacted with $\left[{ }^{14} \mathrm{C}\right]$ penicillin $\mathrm{G}$ and, as shown in Fig. 2, all PBPs that were detected previously in the soluble fraction were also detected in the intact cell.

In order to examine the binding kinetics of $\left[{ }^{14} \mathrm{C}\right]$ penicillin $\mathrm{G}$ to PBPs in the soluble fraction and in the intact cell, cell suspensions or the soluble $S 100$ fraction of C. crescentus CB 13 was incubated with $\left[{ }^{14} \mathrm{C}\right]$ penicillin $\mathrm{G}$ at various concentrations. As shown in Fig. 3, the binding kinetics of $\left[{ }^{14} \mathrm{C}\right]$ penicillin $\mathrm{G}$ to all PBPs were very similar using both methods. $\left[{ }^{14} \mathrm{C}\right]$ Penicillin $G$ showed a high affinity for PBP1A and PBP1Bs. These PBPs were nearly saturated with this antibiotic at $1 \mu \mathrm{g} \mathrm{ml}^{-1}$. PBP2 and PBP3 required a higher concentration of the antibiotic for saturation. Among the soluble PBPs, $\left[{ }^{14} \mathrm{C}\right]$ penicillin $\mathrm{G}$ showed the highest affinity for PBP S3 and the next highest for PBP S2. PBP S1 and PBP S4 did not seem to be saturated with $\left[{ }^{14} \mathrm{C}\right]$ penicillin $\mathrm{G}$ even at $100 \mu \mathrm{g} \mathrm{m} \mathrm{l}^{-1}$. $\left[{ }^{14} \mathrm{C}\right]$ Penicillin $\mathrm{G}$ was shown to have a lower affinity for some PBPs when added to the intact cells, indicating some effect of the outer membrane permeability barrier to the antibiotic.

Release of bound $\left[{ }^{14} \mathrm{C}\right]$ penicillin $G$ from soluble PBPs. Some bacterial PBPs, particularly those of low molecular weight, possess penicillinase-like activity and release bound $\left[{ }^{14} \mathrm{C}\right]$ penicillin $\mathrm{G}$ rapidly during incubation (Shepherd et al., 1977; Spratt, $1977 a$; Chase et al., 1978; Noguchi et al., 1979; Ohya et al., 1979). PBPs of envelope origin in C. crescentus CB13 and CB15 did not have such an activity (Koyasu et al., 1981), and it was of interest to test for penicillinase-like activity of the soluble PBPs.

We examined the release of bound $\left[{ }^{14} \mathrm{C}\right]$ penicillin $\mathrm{G}$ from soluble PBPs as described in Methods. PBP S1 and PBP S2 released bound $\left[{ }^{14} \mathrm{C}\right]$ penicillin $\mathrm{G}$ rapidly. Half the amount of bound $\left[{ }^{14} \mathrm{C}\right]$ penicillin $\mathrm{G}$ was released from these PBPs during $10 \mathrm{~min}$ incubation, while other soluble PBPs did not release bound $\left[{ }^{14} \mathrm{C}\right]$ penicillin $\mathrm{G}$ after $1 \mathrm{~h}$ incubation. 
(a)

(b)

(c)

(d)

(e)

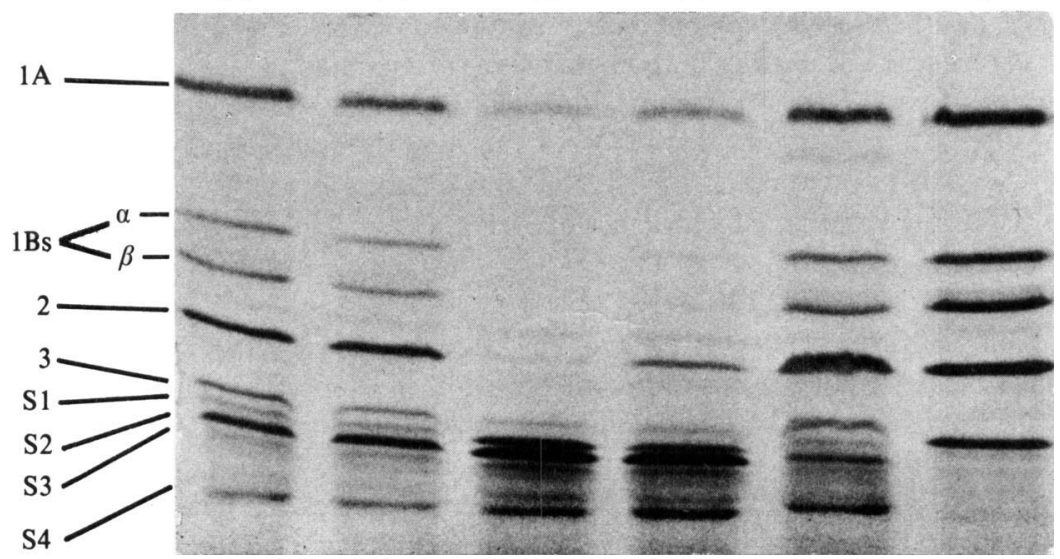

Fig. 1. Penicillin-binding proteins in each fraction of the cell. Samples were incubated with $\left[{ }^{14} \mathrm{C}\right.$ lpenicillin $\mathrm{G}\left(100 \mu \mathrm{g} \mathrm{m}^{-1}\right)$ at $30^{\circ} \mathrm{C}$ for $10 \mathrm{~min}$, mixed with Sarkosyl and non-radioactive penicillin $\mathrm{G}$, and subjected to SDS--polyacrylamide gel electrophoresis (system 2) and subsequent fluorography as described in Methods. The numbers on the left side are the designations of the PBPs. $(a)$ Homogenate; (b) supernatant after centrifuging at $100000 \mathrm{~g}$ for $30 \mathrm{~min}$; (c) S100 fraction; (d) S100' fraction; $(e)$ ribosomal fraction; $(f)$ cell envelopes.

(a)

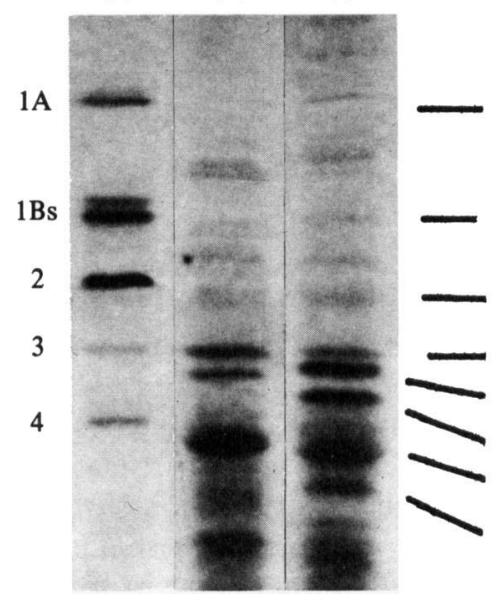

(d)

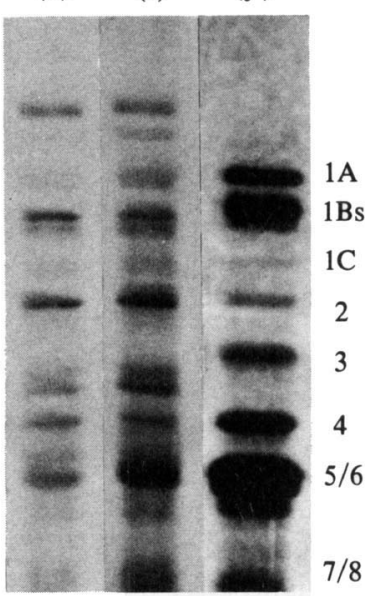

Fig. 2. $\left[{ }^{14} \mathrm{C}\right]$ Penicillin $G$ binding to PBPs in the soluble fraction and in the intact cell. Samples were reacted with $\left[{ }^{14} \mathrm{C}\right.$ lpenicillin $\mathrm{G}$ as described in Methods. The concentrations of $\left[{ }^{14} \mathrm{C} /\right.$ penicillin $\mathrm{G}$ were $100 \mu \mathrm{g} \mathrm{ml}^{-1}(a, b, c, d, f)$ or $300 \mu \mathrm{g} \mathrm{ml}^{-1}(e)$. Gel system 1 was used. The numbers are the designations of envelope-associated PBPs of $C$. crescentus CB15 (left), envelope-associated and soluble PBPs of $C$. crescentus CB13 (middle) and $E$. coli PBPs (right). Cell envelopes of $E$. coli were prepared by the method described previously (Spratt, 1977a; Koyasu et al., 1980a). (a) C. crescentus CB15 cell envelopes: $(b) C$. crescentus CB15 S100 fraction; $(c) C$. crescentus CB13 S100 fraction; $(d, e) C$. crescentus CB13 cell suspension; $(f) E$. coli cell envelopes.

Effect of temperature on soluble PBPs. One of the criteria for the characterization of PBPs is heat sensitivity (Nakagawa et al., 1979; Noguchi et al., 1979; Ohya et al., 1979; Koyasu et al., 1981). To examine differential temperature effects on the ability of PBPs to bind $\left[{ }^{14} \mathrm{C}\right.$ ]penicillin $\mathrm{G}$, the soluble $\mathrm{S} 100$ fraction was incubated at various temperatures for $10 \mathrm{~min}$ prior to PBP assay at $30^{\circ} \mathrm{C}$ (Fig. 4). PBP S2 was thermolabile and its penicillin-binding 


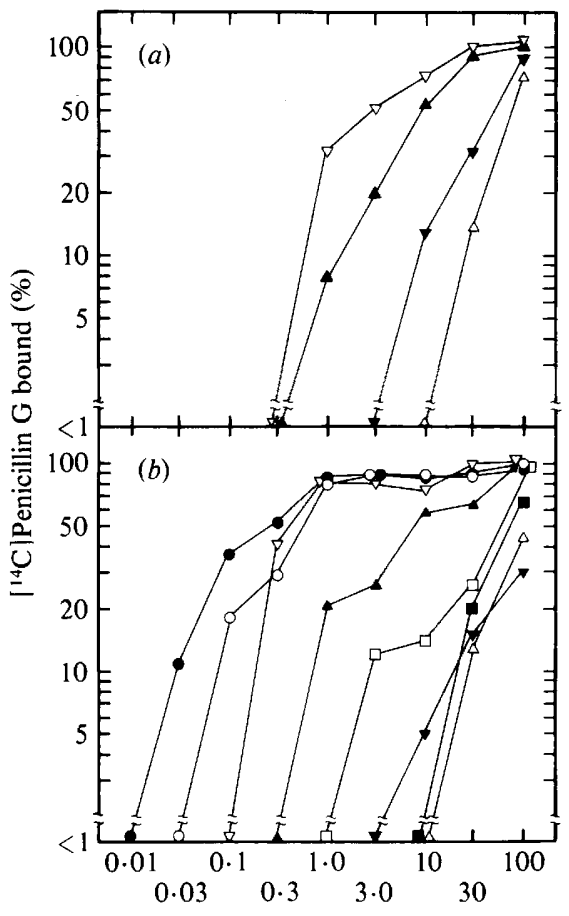

Concn of $\left[{ }^{14} \mathrm{C}\right]$ penicillin $\mathrm{G}\left(\mu \mathrm{g} \mathrm{ml}^{-1}\right)$

Fig. 3. $\left[{ }^{14} \mathrm{C}\right]$ Penicillin $\mathrm{G}$ binding to PBPs. Soluble S100 fraction $(a)$ or cell suspension $(b)$ of $C$. crescentus $\mathrm{CB} 13$ were incubated with $\left[{ }^{14} \mathrm{C}\right.$ ]penicillin $\mathrm{G}$ at final concentrations of 0.01 to $300 \mu \mathrm{g} \mathrm{m}^{-1}$ at $30^{\circ} \mathrm{C}$ for $10 \mathrm{~min}$. The radioactivity bound to PBPs was estimated by densitometry of $\mathrm{X}$-ray films and is plotted as a percentage of the radioactivity observed at $300 \mu \mathrm{g} \mathrm{ml}^{-1} . \mathrm{O}$, PBP1A;O , PBP1Bs; $\square$, PBP2; $\square$, PBP3; $\triangle$, PBP S1; $\triangle$, PBP S2; $\nabla$, PBP S3; $\mathbf{7}$, PBP S4.

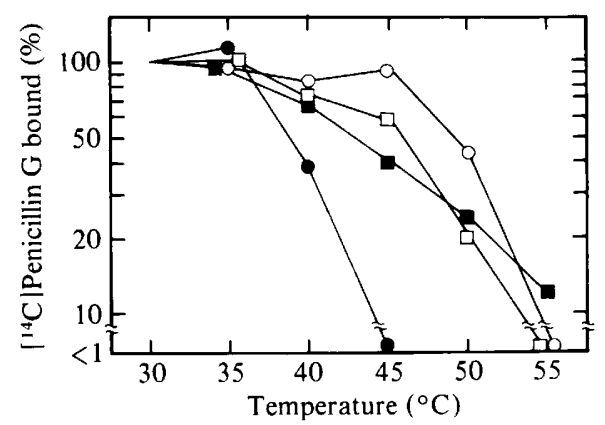

Fig. 4. Effect of temperature on soluble PBPs. The $\mathrm{S} 100$ fraction was pre-incubated at the indicated temperature for $10 \mathrm{~min}$ and then incubated with $\left[{ }^{14} \mathrm{C}\right.$ lpenicillin $\mathrm{G}$ at $30^{\circ} \mathrm{C}$. Slab gel electrophoresis and fluorography were carried out as described in Methods. The radioactivity of bound $\left[{ }^{14} \mathrm{C}\right.$ lpenicillin $\mathrm{G}$ was estimated by densitometry of the film and is plotted as a percentage of the radioactivity bound after pre-incubation at $30^{\circ} \mathrm{C}$ for $10 \mathrm{~min}$. O, PBP S1; , PBP S2; $\square$, PBP S3; 1 , PBP S4.

activity was reduced to $40 \%$ after incubation at $40^{\circ} \mathrm{C}$ for $10 \mathrm{~min}$. The other PBPs were relatively thermostable, especially PBP S1 which was unaffected by incubation at $45^{\circ} \mathrm{C}$. PBP S3 and PBP S4 were less thermostable than PBP S1, and their activity was reduced to about $50 \%$ after incubation at $45^{\circ} \mathrm{C}$ for $10 \mathrm{~min}$ - but residual activity of PBP S4 persisted even after incubation at $55^{\circ} \mathrm{C}$. 


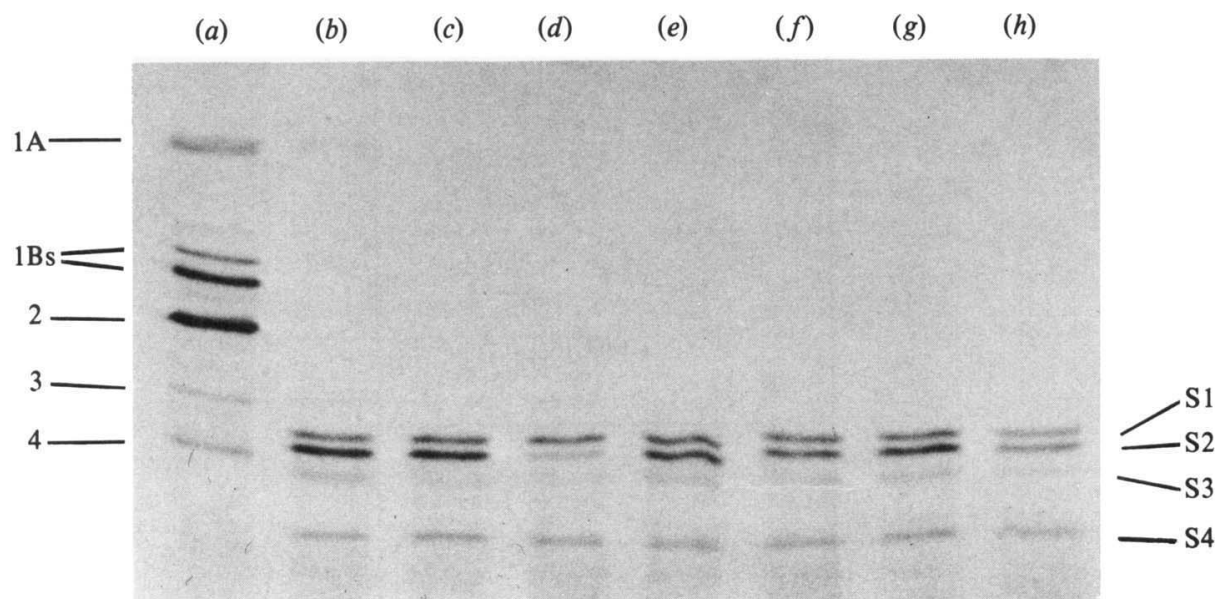

Fig. 5. Affinities of $\beta$-lactam antibiotics for soluble PBPs. Cell envelopes of $C$. crescentus CB15 (a) or the S100 fraction of $C$. crescentus $\mathrm{CB} 13(b-h)$ were incubated with antibiotics or distilled water by the pre-addition method. Antibiotic-PBP and $\left[{ }^{14} \mathrm{C}\right]$ penicillin $\mathrm{G}-\mathrm{PBP}$ complexes were separated by SDS-polyacrylamide gel electrophoresis (system 1). The numbers on the left are the designations of PBPs of the $C$. crescentus CB 15 cell envelope. The numbers on the right are the designations of soluble PBPs of $C$. crescentus CB 13. $(a, b)$, no antibiotic addition; $(c, d)$, apalcillin 0.24 and $6.0 \mu \mathrm{g} \mathrm{ml}^{-1} ;(e, f)$, cephaloridine 0.19 and $4.7 \mu \mathrm{g} \mathrm{ml}^{-1} ;(g, h)$, mecillinam 0.73 and $18 \mu \mathrm{g} \mathrm{ml}^{-1}$.

Effect of related $\beta$-lactam antibiotics on soluble PBPs. Present information indicates that there is a close relationship between the affinity of $\beta$-lactam antibiotics for a particular PBP and their effect on cell morphology (Spratt, 1975; Curtis et al., 1979; Noguchi et al., 1979). As reported previously (Koyasu et al., 1981), differential affinity of $\beta$-lactam antibiotics for PBPs in the Caulobacter cell envelope is quite distinct from that observed for PBPs in other bacteria. In particular, mecillinam, which induces ovoid cells in Gram-negative rod-shaped bacteria, did not show selective affinity for any of the Caulobacter envelope PBPs. In contrast, mecillinam has selective affinity for PBP2 of E. coli (Spratt \& Pardee, 1975; Spratt, 1977a) and a single PBP in other bacteria (Curtis et al., 1979; Noguchi et al., 1979; Ohya et al., 1979; Ogawara \& Horikawa, 1980).

The effects on soluble PBPs of apalcillin, cephaloridine and mecillinam were examined by the pre-addition method (Koyasu et al., 1981). The $\mathrm{S} 100$ fraction and a $\beta$-lactam antibiotic were mixed and incubated at $30^{\circ} \mathrm{C}$ for $10 \mathrm{~min}$ prior to the addition of $\left[{ }^{14} \mathrm{C}\right.$ lpenicillin $\mathrm{G}$. Radioactivity bound to PBPs was detected by electrophoresis and subsequent fluorography. As shown in Fig. 5, the $\beta$-lactam antibiotics did not show a high affinity for the soluble PBPs, compared with the affinity for PBP1A and PBP1Bs in the cell envelope (Koyasu et al., 1981). However, apalcillin exerted an effect on PBP S2 and PBP S3 at $6 \mu \mathrm{g} \mathrm{ml}^{-1}$, while cephaloridine had little effect on the soluble PBPs. Mecillinam did not show selective binding to any of the soluble PBPs at a low concentration $\left(0.73 \mu \mathrm{g} \mathrm{ml}^{-1}\right)$ although it exerted some effect on PBP S1 and PBP S2 at a high concentration $\left(18 \mu \mathrm{g} \mathrm{ml}^{-1}\right)$. From this result and from previous observations (Koyasu et al., 1981), it appears that Caulobacter does not possess a selective target for mecillinam either in the soluble fraction or in the cell envelope. PBP S4 was not affected by the $\beta$-lactam antibiotics tested, as was expected from the result that $\left[{ }^{14} \mathrm{C}\right]$ penicillin $G$ showed a very low affinity for this PBP (Fig. 3).

\section{DISCUSSION}

We have demonstrated the presence in the stalked bacterium $C$. crescentus of at least four PBPs in the soluble fraction, defined as the non-particulate fraction (S100) prepared as described in Methods. Our results suggest that the soluble PBPs are not the products of 
proteolysis during preparation. In addition, the PBPs were observed in the intact cell (Fig. 2). It thus seems likely that the soluble PBPs are present in the cytoplasm and/or periplasm of the living cell. However, the possibility cannot be ruled out at the moment that the soluble PBPs are loosely bound to the envelope so as to be released during preparation, or that they are secreted specifically or cleaved by specific proteases in vivo. Whatever the precise explanation, additional PBPs may be present in the $\mathrm{S} 100$ fraction in other bacteria, and care should therefore be taken to analyse PBPs not only in the envelope but also in the soluble fraction.

PBP S1 and PBP S2 exhibited a penicillinase-like activity as assayed by the release of ${ }^{14} \mathrm{C}$ radioactivity from the $\left[{ }^{14} \mathrm{C}\right]$ penicillin G-PBP complex. Since the patterns of the soluble PBPs changed little when the $\mathrm{S} 100$ fraction was incubated at $30^{\circ} \mathrm{C}$ for $30 \mathrm{~min}$ prior to $\left[{ }^{14} \mathrm{C}\right]$ penicillin $\mathrm{G}$ addition, the degradation of the PBPs during incubation appeared negligible. This penicillinase-like activity was similar to that of PBP5 and PBP6 of E. coli and low molecular weight PBPs of other bacteria (Shepherd et al., 1977; Spratt, 1977a; Chase et al., 1978; Noguchi et al., 1979; Ohya et al., 1979). Since Caulobacter does not possess low molecular weight PBPs which may correspond to E. coli PBP5 and PBP6 in its cell envelope (Koyasu et al., 1980a, 1981), it is possible that PBP S1 and PBP S2 correspond to PBP5 and/or PBP6 of E. coli. It is known that $C$. crescentus possesses a penicillinase activity (Johnson \& Ely, 1977) and is rather resistant to penicillin action. The relationship between the penicillinase activity and the soluble PBPs remains to be investigated.

Caulobacter crescentus CB13 does not possess PBP4 in its envelope, and in C. crescentus CB15 this PBP is located in the outer membrane (Koyasu et al., 1980a, 1981). By contrast, as shown in Fig. 2, C. crescentus CB15 did not possess PBP S2. The heat sensitivity of PBP S2 of $C$. crescentus CB13 was similar to that of PBP4 of $C$. crescentus CB15 (Fig. 4; Koyasu et al., 1981). However, PBP4 of $C$. crescentus CB15 did not show penicillinase-like activity (Koyasu et al., 1981) nor did it co-migrate with PBP S2 of C. crescentus CB13 (Fig. 2; Fig. 5). $\left[{ }^{14} \mathrm{C}\right]$ Penicillin $G$ showed much higher affinity for PBP S2 than for PBP4. These findings suggest that PBP S2 is a different PBP from PBP4. Further studies should serve to clarify the relation of these PBPs.

Both soluble (Fig. 4) and envelope-associated (Koyasu et al., 1981) PBPs of Caulobacter were heat labile compared with those of $E$. coli (Nakagawa et al., 1979). PBP3 and PBP S2 were so heat labile that their ability to bind $\left[{ }^{14} \mathrm{C}\right]$ penicillin $\mathrm{G}$ was lost during incubation at $40{ }^{\circ} \mathrm{C}$ for $10 \mathrm{~min}$.

One approach to elucidate the functions of PBPs is to investigate the relationship between effects on cell morphology and the affinity for PBPs of different $\beta$-lactam antibiotics. In a previous study (Koyasu et al., 1981), it was suggested, from the effect of some $\beta$-lactam antibiotics on PBPs and cell morphology, that PBP3 of the $C$. crescentus cell envelope is involved in cell division. Similar use of $\beta$-lactam antibiotics did not indicate any specificity of the drugs on soluble PBPs. Mecillinam did not show a specific effect on any of the PBPs in either soluble (Fig. 5) or envelope (Koyasu et al., 1981) fractions. Since C. crescentus is resistant to a high concentration of mecillinam, it seems that this organism does not have a specific target for this antibiotic.

\footnotetext{
This work was supported in part by a grant-in-aid from the Ministry of Education, Science and Culture of
} Japan.

\section{REFERENCES}

BonNer, W. M. \& LASkey, R. A. (1974). A film detection method for tritium-labelled proteins and nucleic acids in polyacrylamide gels. European Journal of Biochemistry 46, 83-88.

Chase, H. A., Reynolds, P. E. \& Ward, J. B. (1978).
Purification and characterization of the penicillinbinding protein that is the lethal target of penicillin in Bacillus megaterium and Bacillus licheniformis. Protein exchange and complex stability. European Journal of Biochemistry 88, 275-285. 
Coyette, J., Ghuysen, J.-M. \& Fontana, R. (1980). The penicillin-binding proteins in Streptococcus faecalis ATCC 9790. European Journal of Biochemistry 110, 445-456.

Curtis, N. A. C., Orr, D., Ross, G. W. \& Boulton, M. G. (1979). Competition of $\beta$-lactam antibiotics for the penicillin-binding proteins of Pseudomonas aeruginosa, Enterobacter cloacae, Klebsiella aerogenes, Proteus rettgeri, and Escherichia coli: comparison with anti-bacterial activity and effects upon bacterial morphology. Antimicrobial Agents and Chemotherapy 16, 325-328.

IвA, H. \& OKaDA, Y. (1980). Chromosome segregation in an asymmetrically dividing bacterium, Caulobacter crescentus. Journal of Molecular Bio$\log y$ 139, 733-739.

Iwaya, M., Goldman, R., Tipper, D. J., Feingold, B. \& Strominger, J. L. (1978). Morphology of an Escherichia coli mutant with a temperaturedependent round cell shape. Journal of Bacteriology 136, 1143-1158.

Johnson, R. C. \& ELY, B. (1977). Isolation of spontaneously derived mutants of Caulobacter crescentus. Genetics 86, 25-32.

Koyasu, S., Fukuda, A. \& Okada, Y. (1980a). The penicillin-binding proteins of Caulobacter crescentus. Journal of Biochemistry 87, 363-366.

Koyasu, S., Fukuda, A. \& Okada, Y. (1980 b). Penicillin-binding proteins in soluble fraction of Escherichia coli K-12. Proceedings of the Japan Academy (Series B) 56, 420-424.

Koyasu, S., Fukuda, A. \& OKada, Y. (1981). Properties of the penicillin-binding proteins of Caulobacter. Journal of General Microbiology 126, 111-121.

Laskey, R. A. \& Mills, A. D. (1975). Quantitative film detection of ${ }^{3} \mathrm{H}$ and ${ }^{14} \mathrm{C}$ in polyacrylamide gels by fluorography. European Journal of Biochemistry 56, 335-341.

Leyh-Bouille, M., Dusart, J., NGuyen-Distèche, M., Ghuysen, J.-M., Reynolds, P. E. \& Perkins, H. R. (1977). The peptidoglycan crosslinking enzyme system in Streptomyces strains R61, K15 and rimosus. Exocellular, lysozyme-releasable and membrane-bound enzymes. European Journal of Biochemistry 81, 19-28.

Nakagawa, J., Matsuzawa, H. \& Matsuhashi, M. (1979). Behavior of penicillin-binding proteins in Escherichia coli upon heat and detergent treatments and partial purification of penicillin-binding proteins $1 \mathrm{~A}$ and 1B. Journal of Bacteriology 138, 1029-1032.

Noguchi, H., Matsuhashi, M. \& Mitsuhashi, S. (1979). Comparative studies of penicillin-binding proteins in Pseudomonas aeruginosa and Escherichia coli. European Journal of Biochemistry 100 , 41-49.

Ogawara, H. \& Horikawa, S. (1980). Penicillinbinding proteins of Streptomyces cacaoi, Streptomyces olivaceus, and Streptomyces clavuligerus. Antimicrobial Agents and Chemotherapy 17, 1-7.

Ohya, S., Yamazaki, M., Sugawara, S. \& Matsuhashi, M. (1979). Penicillin-binding proteins in Proteus species. Journal of Bacteriology 137, 474-479.

PoIndeXter, J. S. (1964). Biological properties and classification of the Caulobacter group. Bacteriological Reviews 28, 231-295.

PoIndeXTER, J. S. (1981). The caulobacters: ubiquitous unusual bacteria. Microbiological Reviews $\mathbf{4 5}$, 123-179.

ShAPIRO, L. (1976). Differentiation in the Caulobacter cell cycle. Annual Review of Microbiology 30, $377-407$.

Shepherd, S. T., Chase, H. A. \& Reynolds, P. E. (1977). The separation and properties of two penicillin-binding proteins from Salmonella typhimurium. European Journal of Biochemistry 78, 521-532.

Spratt, B. G. (1975). Distinct penicillin binding proteins involved in the division, elongation, and shape of Escherichia coli K12. Proceedings of the National Academy of Sciences of the United States of America 72, 2999-3003.

SpratT, B. G. $(1977 a)$. Properties of the penicillinbinding proteins of Escherichia coli K12. European Journal of Biochemistry 72, 341-352.

SpratT, B. G. $(1977 b)$. Temperature-sensitive cell division mutants of Escherichia coli with thermolabile penicillin-binding proteins. Journal of Bacteriology 131, 293-305.

Spratt, B. G. \& Pardee, A. B. (1975). Penicillinbinding proteins and cell shape in E. coli. Nature, London 254, 516-517.

Suzuki, H., Nishimura, Y. \& Hirota, Y. (1978). On the process of cellular division in Escherichia coli: a series of mutants of $E$. coli altered in the penicillinbinding proteins. Proceedings of the National Academy of Sciences of the United States of America 75, 654-668.

Tamaki, S., Nakajima, S. \& Matsuhashi, M. (1977). Thermosensitive mutation in Escherichia coli simultaneously causing defects in penicillin-binding protein-1Bs and in enzyme activity for peptidoglycan synthesis in vitro. Proceedings of the National Academy of Sciences of the United States of America 74, 5472-5476. 